\title{
PENGARUH SHOLAT DHUHA TERHADAP KECERDASAN SPIRITUAL ANAK KELOMPOK B USIA 5-6 TAHUN DI TK AR-RAHMAH TANJUNG ATAP
}

\author{
Novita Sari ${ }^{1}$, Dessi Andriani, S.Pd. AUD, M.M² \\ Email : sarinovitaaa66@gmail.com¹, dessiandriani@gmail.com²
}

\begin{abstract}
Abstrak : Penelitian ini bertujuan untuk mengetahui pengaruh kegiatan sholat dhuha terhadap kecerdasan spiritual anak kelompok B2 usia 5-6 tahun di TK Ar-Rahmah Tanjung Atap. Jenis penelitian kuantitatif eksperimen Quasi Eksperimental Jenis Nonequivalent Control Group Design ini terdapat kelompok eksperimen dan kelompok control yang tidak dipilih secara random. Teknik pengumpulan data observasi dan dokumentasi. Sampel penelitian berjumlah 34 orang anak terdiri dari kelas B1 dan B2. Hasil perhitungan menunjukan untuk perolehan data rata-rata Pretest yang pada awalnya anak pada kelas eksperimen sebesar 44,86 dengan kriteria "tidak sesuai" lalu meningkat pada saat Postest dengan nilai rata-rata Postest 69,10 "sesuai". Lalu thitung $=4,68>\mathrm{t}_{\text {tabel2,101 }}$ dengan taraf signifikan (a) 0.05 sesuai dengan criteria pengujian hipotesis, yakni jika $t_{\text {hitung }}>t_{\text {tabe }}$ ${ }_{\text {Imaka }} \mathrm{H}_{\mathrm{a}}$ diterima dan $\mathrm{H}_{\mathrm{o}}$ ditolak. Maka dari itu hipotesis penelitian ini, ada pengaruh sholat dhuha terhadap kecerdasan spiritual anak kelompok B2 usia 5-6 tahun di TK Ar-Rahmah Tanjung Atap.
\end{abstract}

Kata Kunci: Kecerdasan Spiritual, Sholat Dhuha, Anak Usia Dini

\section{PENDAHULUAN}

Pendidikan adalah suatu kebiasaan sekelompok orang yang diturunkan dari satu generasi ke generasi berikutnya, melalui pengajaran, pelatihan atau penelitian untuk mendapatkan pengetahuan, sikap dan keterampilan. Pendidikan yang dimaksudkan tersebut terjadi secara berjenjang yaitu Pendidikan Anak Usia Dini (PAUD), Sekolah Dasar (SD), Sekolah Menengah Pertama (SMP), Sekolah Menengah Atas (SMA), dan kemudian Perguruan Tinggi.
Pada dasarnya pendidikan menyentuh basis yang paling dasar yaitu anak usia dini. Pada masa ini hampir seluruh aspek perkembangan anak mengalami masa kepekaan yang luar biasa dalam aspek perkembangan moral agama, fisik motorik, kognitif, bahasa, sosial emosional dan seni. Pada usia ini pula, anak usia dini sedang menjalani suatu proses perkembangan dengan pesat dan fundamental dikatakan fundamental, karena anak memiliki karakteristik tertentu yang tidak sama dengan orang dewasa, mereka selalu aktif, unik, dinamis antusias, serta 
ingin tahu terhadap apa yang dilihat, didengar dan dirasakan, mereka seolah-olah tak pernah berhenti bereksplorasi dan belajar.

Cara yang efektif untuk merangsang segala aspek pertumbuhan dan perkembangan anak usia dini tersebut yaitu di lembaga Pendidikan Anak Usia Dini (PAUD). Pendidikan Anak Usia Dini (PAUD) adalah suatu lembaga atau instansi terkhusus bagi anak usia nol sampai enam tahun dan merupakan prasyarat untuk mengikuti pendidikan dasar. Pendidikan Anak Usia Dini (PAUD) merupakan salah satu bentuk penyelenggaraan pendidikan yang menitikberatkan pada peletakan dasar kearah pertumbuhan dan perkembangan fisik (koordinasi motorik halus dan kasar), kecerdasan (daya fikir, daya cipta, kecerdasan emosi, dan kecerdasan spirutual), sosial emosional (sikap dan perilaku serta beragama), bahasa dan komunikasi, sesuai dengan keunikan dan tahaptahap pertumbuhan dan perkembangan yang dilalui oleh anak usia dini.
Fenomena yang terjadi pada usia dini 5-6 tahun anak lebih banyak di rumah bersama ibunya dan keluarga, ibu (orang tua) dan keluarga yang ibadahnya senantiasa dikerjakan di rumah pada waktu pagi yaitu sholat dhuha, mengapa waktu pagi menjadi waktu yang sangat efektif untukmenumbuh kembangkan kecerdasan spiritual anak, karena pada waktu pagi daya konsentrasi anak sangat bagus untuk ditumbuh kembangkan dan tak lupa pada dasarnyausia 2-3 tahun ini anak memiliki karakteristik sifat yang meniru dengan apa yang ia lihat dan ia dengar pada lingkungannya, dengan peristiwa inilah secara tidak langsung dan tanpa disadari akan tumbuh dan berkembang kecerdasan spiritual pada anak sejak dini.

Seperti halnya dengan penelitian yang dilakukan oleh Fajariska (2017) dengan judul "Pelaksanaan pembelajaran sholat dhuha melalui metode praktik langsung pada anak usia 5-6 tahun di taman kanak-kanak Islam terpadu Al-Karima kabupaten Kubu Raya” menyatakan bahwa hasil penelitian ini pada siklus I sebelum 
melaksanakan pembelajaran sholat dhuha guru terlebih dahulu mengajak anak wudhu setelah anak belajar, menyiapkan tempat buat sholat dhuha. Siklus II pelaksanaan pembelajaran sholat dhuha terdapat 84\%-100\% anak sudah berkembang sangat baik, mulai berkembang, dan $11 \%-50 \%$ anak belum berkembang. Selanjutnya pada siklus III faktor penghambat anak sulit untuk konsentrasi.Dan pada siklus IV guru tidak mengevaluasi sepenuhnya, guru hanya mendampingi anak dan melatih anak membenarkan gerakan sholat yang belum bisa.

Begitu juga penelitian yang dilakukan oleh Hanifah (2018) dengan judul "Meningkatkan perkembangan bahasa anak melalui Implementasi shalat dhuha pada anak kelompok B Di TK Aisyiyah 12 Jateng Kabupaten Karanganyar tahun ajaran 2016/2017" menyatakan perkembangan berbahasa melalui shalat dhuha pada Siklus I belum berhasil sebesar $47,4 \%$. Siklus II skor rata-rata anak pada perkembangan berbahasa meningkat dengan hasil berkembang sesuai harapan $60,45 \%$ termasuk kategori baik. Perkembangan berbahasa melalui shalat dhuha pada Siklus III sudah berhasil diperoleh rata-rata berkembang sangat baik sebesar $86,8 \%$ dan termasuk kategori sangat baik. Dengan demikian dapat disimpulkan bahwa shalat dhuha mampu meningkatkan perkembangan bahasa pada anak kelompok B di TK Aisyiyah 12 Jateng Kabupaten Karanganyar tahun ajaran 2016/2017.

Kondisi yang tidak jauh berbeda terjadi pada anak kelompok B2 TK Ar-Rahmah Tanjung Atap. Hal ini terlihat ketika anak diberi tantangan untuk berwudhu'oleh guru TK Ar-Rahmah Tanjung Atap, masih banyak anak yang tidak sabar dalam menunggu giliran, anak terlihat malas dan lesu dalam menyanyikan lagu niat dan tata cara berwudhu'. Penyebab masalah tersebut, dikarenakan lebih mengembangkan kemampuan akademik dari pada kecerdasan spiritual anak.

\section{KAJIAN TEORITIK}

\section{Kecerdasan Spiritual}

Menurut Agustian dalam Zubaedi (2017:335) Kecerdasan Spiritual adalah kemampuan untuk 
memberikan makna ibadah terhadap setiap perilaku dan kegiatan, melalui langkah-langkah dan pemikiran tauhid (integralistik) serta berprinsip "hanya karena Allah Swt".

Selanjutnya Zohar dan Marshall dalam Desmita (2016:174) Kecerdasan Spiritual adalah kecerdasan untuk menghadapi dan memecahkan persoalan makna dan nilai, yaitu kecerdasan untuk menempatkan perilaku dan hidup kita dalam konteks makna yang lebih luas dan kaya, kecerdasan untuk menilai bahwa tindakan atau jalan hidup seseorang lebih bermakna dibandingkan dengan yang lain.

Lebih lanjut menurut Wolman dalam Sulastyaningrum (2018:7) kecerdasan spiritual adalah kemampuan manusia untuk mengatasi pertanyaantertinggi tentang makna hidup dan sekaligus untuk menjalin hubungan baik antara kitasatu sama lain dan dunia tempat kita tinggal.

\section{Berdasarkan} beberapa pendapat di atas dapat disimpulkan bahwa kecerdasan spiritual adalah kecerdasan yang sudah dimiliki oleh seseorang sejak lahir, tentang kemampuan mengenai nilai-nilai agama terhadap setiap kegiatan dan perilaku mulia untuk kehidupan selanjutnya.

\section{Sholat Dhuha}

$$
\text { Menurut }
$$

Abdurrahman (2016:69) sholat dhuha adalah shalat sunah yang dilakukan pada waktu matahari sedang naik kurang lebih sejauh 7 hasta. Sedangkan Rahman (2016:1) sholat dhuha adalah sholat sunah yang dilakukan setelah terbit matahari sampai menjelang masuk waktu zuhur.Afdhalnya dilakukan pada pagi hari di saat matahari sedang naik (kira-kira jam 9.00).

Selanjutnya Rohim (2017:96) sholat dhuha adalah sholat yang dikerjakan waktu dhuha, yaitu mulai matahari seujung tombak sampai sebelum tergelincir matahari. Sedangkan yang paling utama dikerjakan ketika matahari mulai terasa panas sekitar jam 9 pagi.

Berdasarkan pemaparan di atas, dapat disimpulkan bahwa sholat dhuha adalah suatu kegiatan sholat sunah yang berjumlah dua rakaat atau lebih dan dilakukan setelah 
terbit matahari, kira-kira waktu paling afdhalnya sholat dhuha ini dilakukan pada pukul sembilan pagi, saat udara masih segar dan matahari sedang berada di posisi yang indah.

\section{Adapun keutamaan sholat} dhuha ialah (a) Sholat dhuha adalah sunah yang diperintahkan oleh Nabi Muhammad SAW secara langsung. (b) Sholat dhuha ciri orang yang bertobat.(c) Sholat dhuha 2 rakaat dapat memenuhi tuntutan bersedekah 360 persediaan setiap hari. (d) Orang yang melaksanakan sholat dhuha akan dicukupi kebutuhannya oleh Allah SWT. (e) Sholat dhuha lebih baik dari pada harta benda.

Jumlah rakaat sholat dhuha yang Diriwayatkan oleh As-Syaibani dan Al-baihaqi dalam Rohim (2017:95) kedudukan orang yang mengerjakan sholat dhuha berdasarkan rakaat adalah sebagai berikut. (a) Orang yang mengerjakan sholat dhuha sebanyak 2 rakaat akan tercatat sebagai orang yang tidak lalai. Dengan sholat dhuha pikiran kita akan jernih kembali sehingga kita mampu bekerja pada kemampuan optimal. (b) Jika dikerjakan 4 rakaat akan tercatat sebagai ahli ibadah dan gemar berbuat hal terbaik. (c) Jika dikerjakan sebanyak 6 rakaat akan terjaga dari perbuatan dosa sepanjang hari itu dan akan tercatat di antara orang-orang yang taat. (d) Jika dikerjakan sebanyak 8 rakaat akan tercatat sebagai orang yang taat dan tercatat pula sebagai bagian dari orang yang sukses. (e) Jika dikerjakan sebanyak 12 rakaat kelak akan dibuatkan sebuah rumah indah terbuat dari emas di surga.

Selanjutnya berikut kaifiyyah tata cara mengerjakan sholat dhuha menurut Rohim (2017:97) sebagai berikut: (a) Niat sholat dhuha USHOLLI SUNNATADH DHUHAA ROK'ATAINI MUSTAQBILAL QIBLATI ADAAAN LILLAHI TA'ALLA. Artinya : Aku niat sholat dhuha dua rakaat menghadap kiblat karena Allah Ta'ala. (b) Takbiratul ihram dilanjutkan membaca do'a iftitah. (c) Membaca surah Al-Fatihah. (d) Membaca surah As-Syams atau AlKafirun (bisa juga membaca surah yang dihafal). (e) Rukuk (membaca 
do'a rukuk 3 kali). (f) I'tidal atau berdiri dari rukuk (membaca do'a i'tidal). (g) Sujud (membaca do'a sujud 3 kali). (h) Duduk diantara dua sujud (membaca do'a duduk diantara dua dua sujud). (i) Sujud kedua (membaca do'a sujud 3 kali). (j) Berdiri rakaat kedua. (k) Membaca surah Al-Fatihah. (1) Membaca surah Ad-Dhuha atau Al-Ikhlas (surah yang dihafal). (m) Rukuk (membaca do'a rukuk 3 kali). (n) I'tidal atau berdiri dari rukuk (membaca do'a i'tidal). (o) Sujud (membaca do'a sujud 3 kali). (p) Duduk diantara dua sujud (membaca do'a duduk diantara dua dua sujud). (q) Sujud kedua (membaca do'a sujud 3 kali). (r) Tasyahud akhir (membaca do'a tasyahud akhir atau tahiyyat). (s) Salam.

\section{METODOLOGI PENELITIAN}

Dalam penelitian ini terdapat dua variabel yaitu variabel independen (bebas) dan variabel dependen (terikat). Variabel (bebas) pada penelitian ini adalah sholat dhuha $(\mathrm{X})$, dan variabel terikat pada penelitian ini adalah kecerdasan spiritual (Y). Peneliti mengambil lokasi di TK Ar-Rahmah Tanjung Atap yang terletak di Jalan Inpres, Kecamatan Tanjung Batu.TK ArRahmah Tanjung Atap merupakan sekolah swasta yang ada di desa Tanjung Atap.Penelitian ini memilih TK Ar-Rahmah Tanjung Atap dengan prioritas anak kelas B2 berjumlah 19 anak. Dan Waktu penelitian ini dilaksanakan pada tanggal 17 Juli 2019 sampai dengan 25 Juli 2019. Metode penelitian yang dilakukan dalam penelitian ini adalah menggunakan metode Quasi Eksperimental jenis Nonequivalent Control Group Design.

Menurut

Hikmawati (2017:60) menyatakan bahwa populasi adalah wilayah generalisasi terdiri dari subjek/objek yang mempunyai kuantitas dan karakteristik tertentu yang ditetapkan oleh peneliti untuk dipelajari dan kemudian diambil kesimpulannya. Populasi penelitian ini adalah seluruh peserta didik kelas B di TK ArRahmah Tanjung Atap. Menurut Arikunto (2014:174) sampel adalah sebagian atau wakil populasi yang diteliti. Sedangkan menurut Sugiyono (2017:63) dikenal juga 
dengan sampling pertimbangan yang digunakan peneliti jika peneliti mempunyai pertimbanganpertimbangan tertentu di dalam pengambilan sampel atau menentukan sampel untuk tujuan tertentu. Maka teknik pengambilan sampel dalam penelitian ini yaitu dengan cara Sampling purposive karena sampel yang akan diambil disesuaikan dengan kebutuhan pnelitian. Jadi sampel dalam penelitian ini adalah anak kelompok B2 di TK Ar-Rahmah Tanjung Atap dengan jumlah sampel yang digunakan adalah 19 anak, 10 orang anak laki-laki dan 9 orang anak perempuan, dan anak kelompok B1 menjadi kelas kontrol.

Rancangan Perlakuan dalam penelitian ini adalah tahap pemberian tes awal (pretest) baik kelas eksperimen maupun kelas kontrol berupa kegiatan berwudhu'. Tahap pemberian perlakuan (treatment) yaitu dengan mengajak anak melakukan kegiatan sholat dhuha, dengan teratur dan tertib. Tetapi perlakuan ini hanya diberikan kepada kelas ekspermen saja dan tidak diberikan pada kelas kontrol.
Selanjutnya tahap tes akhir (posttest) dilakukan dan dinilai sama pada saat dilakukannya pretest.

Teknik pengumpulan data penelitian ini yaitu dengan observasi dan dokumentasi. Hadi dalam Sugiyono (2017:203) menyatakan bahwa, observasi merupakan suatu proses yang kompleks, suatu proses yang tersusun dari berbagai proses biologis dan psikologis. Dua di antara yang terpenting adalah prosesproses pengamatan dan ingatan. Dalam penelitian ini observasi dilakukan dengan mengamati guru dan anak selama proses belajar mengajar. Sedangkan Sumber data dokumentasi dalam penelitian ini adalah berupa foto dan rekam video kegiatan pada saat anak melakukan sholat dhuha untuk mengetahui kecerdasan spiritual anak. Dengan adanya dokumentasi berupa foto dan video maka dapat menggambarkan detail peristiwa-peristiwa penting pada saat dilakukannya penelitian serta sebagai bukti bahwa penelitian ini memang benar-benar dilakukan.

Hasil uji coba instrumen dengan pendapat dari ahli (Judgement Experts). Setelah 
instrwumen disusun tentang aspekaspek yang akan diukur dengan berlandaskan teori, maka selanjutnya dikonsultasikan dengan ahli tentang kecerdasan spiritual yang akan diujikan kepada anak. Adapun kisikisi instrumen kecerdasan spiritual sebagai berikut: (a) Anak mampu mengenal agama yang dianutnya. (b) Anak mampu beribadah sesuai tuntunan orang dewasa. (c) Anak mampu mengucapkan kata santun. (d) Anak mampu membedakan perilaku baik dan buruk.

\section{HASIL DAN PEMBAHASAN}

\section{Hasil}

a. Uji Normalitas Data

Data posttest kelas eksperimen uji normalitas data adalah -0,20 dan pretest diperoleh 0,58 . Harga tersebut terletak antara (1) dan (1) sehingga dapat dikatakan bahwa data kelas tersebut terdistribusi normal.

\section{b. Uji Homogenitas Data}

Hasil perhitungan uji homogenitas untuk $F_{\text {hitung }} \leq \mathrm{F}_{\text {tabel }}$ atau $1,71 \leq 4,45$, maka variansvarians dinyatakan homogen. Selanjutnya satelah pengujian normalitas data dan homogenitas data tersebut dilakukan dan dinyatakan data tersebut terdisribusi normal dan varians dalam peneltian tersebut homogen, maka tahapan berikutnya dilakukan pengujian hipotesis.

\section{c. Uji Hipotesis}

Dari hasil perhitungan uji-t di atas diperoleh nilai $t_{\text {hitung }}=1,71$ jika dibandingkan dengan $\mathrm{t}_{\text {tabel }} 18$ adalah 2,101 , berarti $t_{\text {hitung }}>t_{\text {tabel }}$ maka tolak Ho dan diterima $\mathrm{Ha}$, ini berarti hipotesis yang menyatakan bahwa kegiatan sholat dhuha memiliki pengaruh yang signifikan terhadap kecerdasan spiritual pada anak kelompok B2 usia 5-6 tahun di TK Ar-Rahmah Tanjung Atap.

\section{Pembahasan}

Kecerdasan spiritual anak perlu mendapatkan stimulasi supaya dapat berkembang secara optimal, sehingga diperlakukan suatu kegiatan yang menarik salah satunya ialah dengan sholat dhuha. Sholat dhuha merupakan salah satu hal yang harus diketahui dan dikerjakan anak, karena melalui sholat dhuha anak akan 
memperoleh pengetahuan, dan menanamkan sifat kesabaran pada anak sejak dini. Ketika hendak sholat dhuha anak dapat melatih kesabaran menunggu giliran saat mau berwudhu'. Kegiatan sholat dhuha merupakan salah satu kegiatan yang dapat dilakukan anak di sekolah untuk mengembangkan aspek perkembangan, terutama kecerdasan spiritual.

Sejalan dengan hal tersebut, hasil penelitian ini dukung oleh Hanifah (2018) dengan judul "Meningkatkan perkembangan bahasa anak melalui Implementasi shalat dhuha pada anak kelompok B Di TK Aisyiyah 12 Jateng Kabupaten Karanganyar tahun ajaran 2016/2017" menyatakan perkembangan berbahasa melalui shalat dhuha pada Siklus I belum berhasil sebesar 47,4\%. Siklus II skor rata-rata anak pada perkembangan berbahasa meningkat dengan hasil berkembang sesuai harapan $60,45 \%$ termasuk kategori baik. Perkembangan berbahasa melalui shalat dhuha pada Siklus III sudah berhasil diperoleh rata-rata berkembang sangat baik sebesar
86,8\% dan termasuk kategori sangat baik. Dengan demikian dapat disimpulkan bahwa shalat dhuha mampu meningkatkan perkembangan bahasa pada anak kelompok B di TK Aisyiyah 12 Jateng Kabupaten Karanganyar tahun ajaran 2016/2017.

Berdasarkan uraian di atas dapat dikatakan dan dibuktikan kebenarannya bahwa terdapat pengaruh sholat dhuha terhadap kecerdasan spiritual anak. Dalam penelitian ini digunakan instrumen penelitian berupa lembar observasi untuk mengetahui nilai rata-rata pretest dan posttest. Adapun nilai rata-rata pretest yang pada awalnya sebesar 44,86 (tidak sesuai) lalu meningkat pada saat posttest dengan nilai rata-rata post-test69,10 (sesuai). Hal ini dapat diartikan bahwa kegiatan sholat dhuha memberikan pengaruh yang positif terhadap kecerdasan spiritual anak kelompok B2 usia 5-6 Tahun di TK Ar-Rahmah Tanjung Atap.

Adapun hasil perhitungan yang di dapat untuk posttest, uji normalitas data yang diperoleh adalah -0,20 dan pretest diperoleh - 
0,58 . Harga tersebut terletak antara (1) dan (1) sehingga dapat dikatakan bahwa data kelas tersebut terdistribusi normal. Kemudian hasil perhitungan uji homogenitas untuk $F_{\text {hitung }} \leq \mathrm{F}_{\text {tabel }}$ atau $1,71 \leq 4,45$, maka varians-varians dinyatakan homogen. Selanjutnya satelah pengujian normalitas data dan homogenitas data tersebut dilakukan dan dinyatakan data tersebut terdisribusi normal dan varians dalam peneltian tersebut homogen, maka tahapan berikutnya dilakukan pengujian hipotesis dari hasil perhitungan uji-t di atas diperoleh nilai $t_{\text {hitung }}=1,71$ jika dibandingkan dengan $\mathrm{t}_{\text {tabel }} 18$ adalah 2,101, berarti $t_{\text {hitung }}>t_{\text {tabel }}$ maka tolak Ho dan diterima Ha, ini berarti hipotesis yang menyatakan bahwa kegiatan sholat dhuha memiliki pengaruh yang signifikan terhadap kecerdasan spiritual pada anak kelompok B2 usia 5-6 tahun di TK Ar-Rahmah Tanjung Atap.

\section{SIMPULAN DAN SARAN}

Dapat disimpulkan bahwa:

1. Sholat dhuha adalah sholat sunah yang dilakukan ketika matahari sedang menyengat kira-kira jam 9.

2. Sholat dhuha adalah sholat sunah yang dilakukan seseorang pada pagi hari kira-kira jam 9.

3. Sholat dhuha adalah sholat yang dilakukan pagi hari yaitu pada waktu matahari sedang indah kira-kira pukul 9.

4. Dari hasil penelitian yang peneliti lakukan dapat dikatakan dan ibuktikan kebenarannya bahwa terdapat pengaruh sholat dhuha terhadap kecerdasan spiritual anak. Dalam penelitian ini digunakan instrumen penelitian berupa lembar observasi untuk mengetahui nilai rata-rata pretest dan posttest. Adapun nilai rata-rata pretest yang pada awalnya sebesar 44,86 (tidak sesuai) lalu meningkat pada saat posttest dengan nilai rata-rata post-test69,10 (sesuai). Hal ini dapat diartikan bahwa kegiatan sholat dhuha memberikan pengaruh yang positif terhadap kecerdasan spiritual anak kelompok B2 usia 5-6 Tahun di TK Ar-Rahmah Tanjung Atap. 
Peneliti memberikan saran untuk:

\section{Sekolah}

Hendaknya tetap menjaga dan menciptakan lingkungan sekolah agar tetap harmonis dan terjalin kekeluargaan antar guru, orang tua dan anak didik dalam proses pembelajaran, sehingga dapat sama-sama mengembangkan dan meningkatkan mutu pendidikan.

2. Guru

Diharapkan dapat menjadi referensi tambahan untuk menambah kegiatan pembelajaran dengan kegiatan sholat dhuha terutama dalam mengemabangkan kecerdasan spiritual anak.

3. Orang tua

Diharapkan orang tua mempunyai waktu khusus untuk mengembangkan keceradasan spiritual anak melalui kegaiatan sholat dhuha yang bisa diajarkan ke anak di rumah.

\section{DAFTAR PUSTAKA}

Abd. Rohim, Nasrudin. (2017). 5 Shalat Pembangun Jiwa. Jakarta Selatan : Qultum Media.
Abdurrahman, Tarmidzi. (2016). Buku Shalat Panduan dan Tuntunan Praktis. Jakarta Selatan : Wahyumedia.

Arikunto, Suharsimi. 2014. Prosedur Penelitian. Jakarta : Rineka Cipta.

Desmita. (2016). Psikologi Perkembangan. Bandung : Remaja Rosdakarya.

Fajariska, Aisya. (2017). Pelaksanaan pembelajaran sholat dhuha melalui metode praktik langsung pada anak usia 5-6 tahun di taman kanak-kanak Islam terpadu Al-Karima kabupaten Kubu Raya.

http://openjurnal.unmuhpnk.a c.id/index.php/JME/article/vi ew/1345.

Hanifah, Arrum. Meningkatkan Perkembangan Bahasa Anak Melalui Implementasi Shalat Dhuha Pada Anak Kelompok B Di Tk Aisyiyah 12 Jaten Kabupaten Karanganyar Tahun Ajaran 2016/2017. Skripsi thesis, Universitas Muhammadiyah Surakarta. http://eprints.ums.ac.id/id/epri nt/61252.

Hikmawati, Fenti. 2014. Metodologi penelitian. Depok : PT Rajagrafindo Persada.

Rahman, Arif. (2016). Keberkahan Sholat Dhuha Raih Rezeki Sepanjang Hari.Jakarta: Shahih. 
Sugiyono. (2017). Metode Penelitian Pendidikan Pendekatan Kuantitatif, kualitatif, dan $R \& D$. Bandung : Alfabeta.

Sulastyaningrum, Rizky. (2018). Pengaruh Kecerdasan Intelektual, Kecerdasan Emosional, dan Kecerdasan Spiritual terhadap Prestasi Belajar Mata Pelajaran Ekonomi pada Peserta Didik Kelas XI IPS di SMA Negri 1 Bulu Tahun Ajaran 2017/2018.

http://jurnal.fkip.uns.ac.id./in dex.php/ptn.

Zubaedi. (2017). Strategi Taktis Pendidikan Karakter (Untuk PAUD dan Sekolah). Depok : Rajagrafindo Persada. 